\title{
ANALISIS PERSEPSI KUALITAS PERKULIAHAN DI LABORATORIUM PERKANTORAN DAN SEKRETARI PROGRAM PENDIDIKAN VOKASI UNIVERSITAS INDONESIA
}

\author{
Istiadi $^{1}$ \\ Mohammad Ridha ${ }^{2}$ \\ 1,2 Laboratorium Administrasi Perkantoran dan Sekretari, Program Vokasi Universitas Indonesia \\ ${ }^{3}$ Laboratorium Keuangan dan Perbankan, Program Vokasi Universitas Indonesia
}

\section{Diterima : 13 November 2015}

Layak Terbit : 1 Januari 2016

Abstrak

Laboratorium suatu program studi merupakan salah satu faktor yang mempengaruhi kualitas mahasiswa dan mahasiswi dalam suatu proses pembelajaran di Program Pendidikan Vokasi. Untuk itu Laboratorium harus menjadi salah satu ujung tombak didalam menciptakan lulusan yang berkualitas.

Kualitas pembelajaran di laboratorium itu sendiri secara umum dipengaruhi oleh faktor faktor seperti : pengajar, bahan ajar/ kurikulum di laboratorium serta alat-alat/fasilitas penunjang di laboratorium. Untuk itulah pada kesempatan penelitian itu penulis ingin mengetahui bagaimana persepsi umum para mahasiswa yang sudah merasakan kuliah didalam laboratoium menurut pandangan mereka. Faktor faktor yang diteliti antara lain meliputi tingkat kepuasan mereka terhadap kualitas pengajar di laboratorium, kualitas pengajaran yang digunakan serta persepsi mereka terhadap peralatan yang ada di Laboratorium Perkantoran dan Sekretari. Hasil dari penelitian ini akan sangat berguna sebagai suatu masukan didalam mengembangkan Laboratorium Perkantoran dan Sekretari yang lebih ideal yang sesuai dengan kebutuhan para mahasiswa.

Kata kunci; Laboratorium, Kualitas pengajaran, fasilitas , kurikulum, kepuasan mahasiswa

\begin{abstract}
Laboratory of the study Program is the on factor that imfluence the quality of student in the process of their study in Vocational Program. In order that, laboratory must become the crucial factor in producing qualified alumni.

The quality of teaching ini laboratory in general was imfluenced some factors like: lecturer/instructur, curicullum, tools or su pported facilities in laboratory. For that reason, in this research we want to know the general of student in laboratory teaching. Factors that was identified included : degree of student satisfaction, quality of teaching, and laboratory supporting facilities. Output of this research is benefited as the input in developing the ideal office and Secretary Laboratory that sincronized with student needs.
\end{abstract}

Keyword; Laboratory, quality of teaching, facility, curicullum, student satisfaction.

\section{PENDAHULUAN}

Keberadaan Laboratorium dalam

suatu pendidikan vokasional memegang peranan yang sangat penting mengingat pendidikan vokasional merupakan skema pendidikan yang sengaja dipersiapkan agar lulusannya siap bekerja. Menurut PERMENPAN No. 3 Tahun 2010, 
Laboratorium adalah unit penunjang akademik pada lembaga pendidikan, berupa ruangan tertutup atau terbuka, bersifat permanen atau bergerak, dikelola secara sistematis untuk kegiatan pengujian, kalibrasi, dan/atau produksi dalam skala terbatas, dengan menggunakan peralatan dan bahan berdasarkan metode keilmuan tertentu, dalam rangka pelaksanaan pendidikan, penelitian, dan/atau pengabdian kepada masyarakat.

Penulis memperhatikan bahwa Laboratorium Perkantoran dan Sekretari sudah memenuhi PERMENPAN No.3 Tahun 2010 tersebut, namun untuk mengoptimalkan pendayagunaan dan pelayanan di laboratorium, perlu diadakan pengkajian terhadap kualitasnya.

Untuk itu kualitas pembelajaran di Laboratorium seharusnya memiliki kualitas yang baik yang mendukung pembelajaran didalam kelas, sebagai sarana praktikum dan pengujian. Di lingkungan Program Studi Administrasi Perkantoran dan Sekretari sendiri keberadaan Laboratorium Perkantoran dan Sekretari dapat di katakan masih tergolong baru. Laboratorium Perkantoran dan Sekretari dimanfaatkan untuk memberikan atmosfir perkantoran moderen, dengan peralatan dan perlengkapan manual maupun elektronik. Seiring dengan perkembangan keilmuan dan teknologi, sarana dan prasarana Laboratorium Perkantoran dan sekretari dilengkapi dengan sistem teknologi informasi terkini dan diharapkan dapat menjadi role model bagi pendidikan vokasional lainnya.Pembekalan untuk para dosen dioptimalkan melalui kerjasama dengan industri dan asosiasi profesi, agar modul yang disusun sesuai dengan kebutuhan para stake holder-nya.

Keberadaan laboratorium yang dapat dikatakan masih tergolong baru ini, pada dasarnya masih perlu banyak pembenahan disana sisi. Berbagai aspek memang masih perlu pembenahan dan pengembangan karena laboratorium merupakan salah satu faktor yang menjadi ujung tombak didalam meningkatkan kualitas pembelajaran di Program Pendidikan Vokasi UI. Keberadaan laboatorium yang lengkap dan ideal bukan hanya menjadi persyaratan untuk mendapatkan akreditasi yang sempurna tetapi juga untuk dapat menghasilkan lulusan yang berkualitas.

Disamping ditentukan oleh kualitas mahasiswa sendiri kualitas lulusan juga dipengaruhi oleh faktor utama lainnya seperti:

- Kualitas Pengajar

- Kualitas Kurikulum atau bahan pembelajaran yang digunakan

- Keberadaan sarana penunjang laboratorium

Untuk itulah dalam rangka mencari masukan tentang pandangan mahasiswa terhadap ketiga komponen diatas maka penelitian ini dilakukan.Berdasarkan uraian pada latar belakang di atas, dapat dirumuskan pokok permasalahan yang menjadi fokus penelitian yaitu:

1. Bagaimana kualitas pengajaran dosen di dalam laboratorium?

2. Bagaimana kualitas bahan pembelajaran yang digunakan di laboratorium, apakah 
sudah memuaskan penggunanya?

3. Bagaimana kelengkapan peralatan materi yang ada di dalam laboratorium menurut mahasiswa pengguna laboratorium?

\section{TUJUAN DAN MANFAAT PENELITIAN}

\section{Tujuan Penelitian}

1. Mengetahui bagaimana kualitas pengajaran dosen di dalam laboratorium kualitas

2. Mengetahui pendapat mahasiswa mengenai kelengkapan peralatan dan sarana pelayanan penunjang dilaboratorium

3. Mengetahui berbagai kekurangan yang masih dijumpai di laboratorium

\section{Manfaat Penelitian}

Adapun manfaat yang dapat diambil dari penelitian ini antara lain:

1. Sebagai masukan bagi Program Studi ataupun Kepala Laboratorium didalam mengambil kebijakan khususnya yang berkaitan dengan perkuliahan di laboratorium.

2. Meningkatkan kemampuan dosen tetap didalam aktivitas penelitian di Program Pendidikan Vokasi Universitas Indonesi

\section{METODOLOGI PENELITIAN}

Bab ini akan memberikan penjelasan tentang jenis penelitian, pendekatan penelitian, teknik pengumpulan data, populasi, sampel, dan teknik analisis data yang digunakan dalam penelitian.

Penelitian ini merupakan penelitian deskriptif kuantitatif, yaitu penelitian untuk membuat sutau penilaian terhadap suatu kondisi dan penyelenggaraan suatu program di masa sekarang, kemudian hasilnya digunakan untuk menyusun suatu perencanaan perbaikan program tersebut.

Jenis penelitian kuantitatif karena menekankan analisisnya pada data-data numerikal (angka) yang diolah dengan metode statistika Pendekatan yang digunakan survey, yaitu memberikan kuisioner kepada mahasiswa. Pendekatan waktu yang digunakan dengan cross sectional dimana variabel diteliti pada waktu bersamaan.

\section{Pendekatan Penelitian}

Metode yang digunakan dalam penelitian ini adalah metode deskriptif analisis dengan pendekatan kuantitatif, yaitu penelitian yang kemudian diolah dan dianalisis untuk diambil kesimpulan.

\section{Jenis Penelitian}

Penelitian ini termasuk kedalam jenis penelitian deskriptif yang dilakukan untuk dapat memberikan gambaran yang lebih jelas dan detail mengenai fenomena yang terkait dengan kualitas Penyelenggaraan di Laboratorium Perkantoran dan Sekretaris Program Pendidikan Vokasi UI.

\section{Lokasi dan waktu Penelitian}

Lokasi Penelitian ini bertempat di Laboratorium Perkantoran dan Sekretari Program Pendidikan Vokasi UI. Waktu Peneltian ini dilakukan pada semester genap dan semester ganjil tahun ajaran 2014/2015 


\section{Teknik Pengumpulan Data}

Teknik pengumpulan data penelitian mempunyai tujuan untuk mendapatkan atau mengumpukan data/informasi yang dapat menjelaskan dan atau menjawab permasalahan penelitian secara objektif. Untuk mengumpulkan data serta informasi yang diperlukan oleh penulis adalah pendekatan survey dengan menggunakan metode penyebaran Daftar Pertanyaan (Kuisioner) kepada mahasiswa (sampelnya )

Teknik pengumpulan data dengan jalan melakukan pembagian daftar pertanyaan langsung ke objek penelitian (kuisioner) sehingga data yang penulis kumpulkan benarbenar sesuai dengan keadaan yang sebenarnya pada saat penelitian berlangsung.

\section{Populasi dan Sampel}

Populasi merupakan keseluruhan data sementara sample merupakan bagian dari populasi yang diambil dengan metode tertentu sehingga mewakili populasi. Populasi tidak harus selalu besar, tergantung riset yang dilakukan (Trihendradi). Pada penelitian pesepsi kepuasan Mahasiswa pengguna labotorium Perkantoran ini opulasinya adalah seluruh mahasiswa yang pernah menggunakan laboratiotium Perkantoran dan Sekretari di Prodi APS ini. Sementara sampel-nya adalah menggunakan metode sampling

\section{Teknik Analisis Data}

Adapun tehnik analisis data yang digunakan adalah teknik analisis data kuntitatif. Adapun untuk mempermudah pengukuran perasaan atau pendapat seseorang tentang sesuatu digunakan skala. Skala merupakan kelas ukuran data kuantitatif yang sering digunakan dalam penelitian survey.

Skala Likert merupakan skala yang digunakan untuk mengukur sikap, pendapat, dan persepsi seseorang atau sekelompok orang tentang fenomena sosial. Pengukuran data yang digunakan dalam penelitian ini adalah skala likert karena akan mengukur variabel penelitian seperti sikap, pendapat dan persepsi seseorang atau sekelompok orang. Variabel penelitian yang diukur dengan skala likert ini, dijabarkan kedalam indikator variabel yang kemudian dijadikan titik tolak penyusunan butir-butir instrumen. Instrumen penelitian yang menggunakan skala likert dibuat dalam bentuk multiple choice.

\section{Hasil Penelitian}

Dari hasil Penelitian yang dilakukan terhadap 120 orang mahasiswa yang pernah menggunakan laboratorium Perkantoran dan Sekrearis di Prodi APS terhadap berbagai aspek penilaian seperti kelngkapan alat laboratorium, lay out ruangan, jumlah meja dan kursi diperoleh sebagai berikut : 


\section{Kelengkapan Alat}
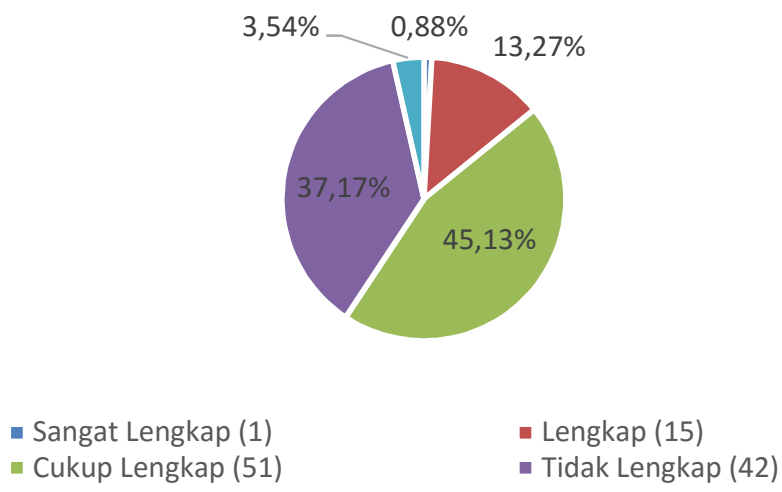

\section{Gambar 1. Kelengkapan alat}

Sumber : Hasil Riset 2015

$45.13 \%$ responden menyatakan cukup lengkap, mengindikasikan bahwa laboratorium sudah dapat beroperasi dengan standar menengah. Dianggap sudah dapat memenuhi kriteria laboratorium yang menjadi sarana praktikum dan mengedukasi. Namun indikasi ukuran "cukup" dapat diartikan bahwa kemungkinan hanya dapat berkembang dalam jangka waktu belum menengah, belum tentu dapat mengantisipasi perkembangan keilmuan dan industry jangka panjang.

$37.17 \%$ responden menyatakan tidak lengkap, mengindikasikan ancaman bahwa laboratorium segera usang dan tidak dapat mengantisipasi perkembangan keilmuan dan tuntunan industri.

\section{Lay Out / Ruangan}

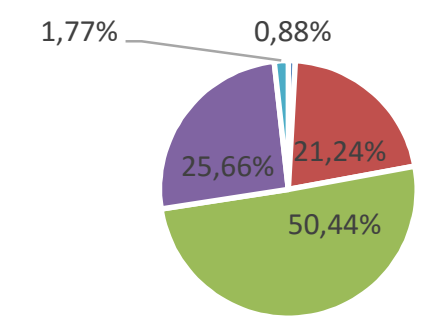

\section{Gambar 2. Lay out / Ruangan}

Sumber : Hasil Riset 2015 
Dari penelitian mengenai lay out ruang laboratorium, sebanyak 21,44\% responden menyatakan sesuai dengan kondisi kantor yang selama in mereka lihat. Sementara mayoritas responden yaitu 50,44 \% responden menyatakan cukup sesuai, mengindikasikan bahwa masih perlu peningkatan yang signifikan. Survey dan observasi mendalam ke berbagai kantor pada industri menengah dan besar merupakan cara yang dapat mensinergikan kondisi sekarang dengan realita yang ada. Kemiripan dengan kondisi perkantoran sesungguhnya merupakan syarat mutlak. Simulasi yang dilakukan pada lingkungan yang identik. diharapkan menghasilkan lulusan yang mempunyai kompetensi yang sesuai standar asosiasi profesi dan industri. Sementara itu 25,66 \% atau sebesar 29 orang responden menyatakan tidak sesuai mengindikasikan bahwa kondisi tang ada belum layak untuk menjadi tempat sarana praktikum. Dapat diperkirakan terjadi kebingungan dan lambatnya adaptasi para mahasiswa ketika magang ataupun bekerja kelak.

\section{Jumlah Meja dan Kursi}
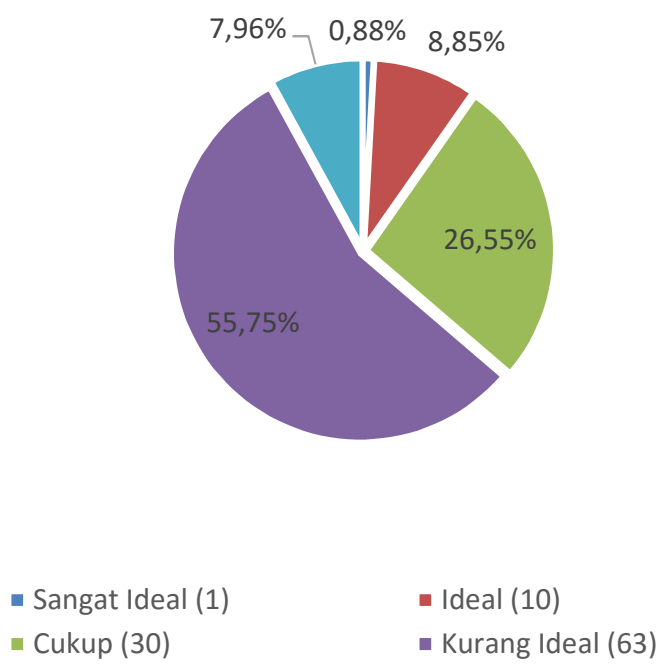

\section{Gambar 3. Jumlah Meja dan Kursi}

Sumber : Hasil Riset 2015

\begin{abstract}
$55,75 \%$ responden menyatakan kurang ideal, mencerminkan ketidaknyamanan mereka ketika melakukan praktikum. Kondisi ini diperkirakan dapat mengganggu daya serap terhadap materi yang disampaikan. Jika tidak disesuaikan, kondisi ini dapat membuat banyak mahasiswa yang merasakan tidak total ketika berpraktikum. Keresahan yang timbul akibat
\end{abstract}

ketidaknyamanan sangat mengurangi kualitas pengajaran. 26,55 \% responden menyatakan cukup, belumlah menjadi indikator yang melegakan. Ada kemungkinan, pada beberapa sesi, ada yang menunggu fasilitas selesai dipakai responden lainnya. Masa tunggu pergantian fasilitas walaupun hanya sebentar akan mengganggu flow kegiatan secara keseluruhan. Waktu praktikum yang 
memanjang tidak dapat ditolerir pada mengurangi kelengkapan materi yang

pemakaian laboratorium. Dapat terjadi disampaikan.

penghentian praktikum, karena lab akan

dipakai kelompok lainnya. Kondisi ini dapat

\section{Kelayakan Peralatan}
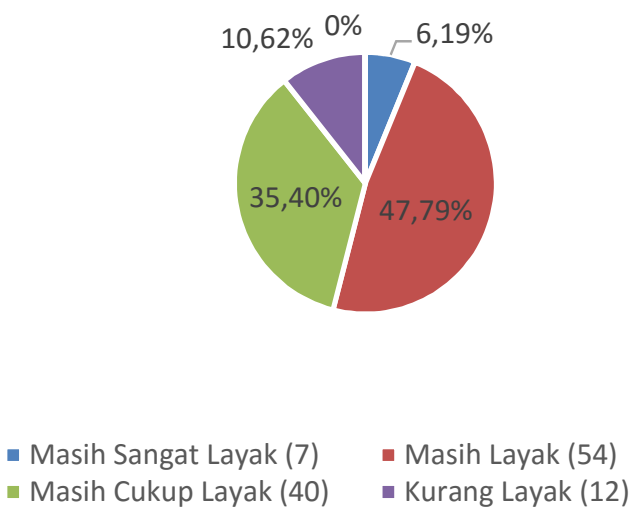

\section{Gambar 4. Kelayakan Peralatan}

Sumber : Hasil Riset 2015

$47,79 \%$ responden menyatakan masih layak digunakan, mengindikasikan bahwa unsur kekinian dan daya tahan alat masih dapat diandalkan dalam jangka waktu panjang. Pemeliharaan peralatan mutlak dilakukan secara rutin, karena banyaknya pemakai lab yang berganti-ganti, tentunya penggunaan peralatan tidak stabil. Beberapa pemakai peralatan dapat menggunakannya sesuai standar, namun dikhawatirkan banyak yang pemakaiannya tidak benar prosedurnya/
$35.40 \%$ menyatakan masih cukup layak mengindikasikan bahwa dapat saja terjadi kerusakan dan keusangan dalam jangka menengah. Beberapa responden sudah merasakan adanya pengurangan kualitas peralatan dan dapat mengganggu jalannya praktikum. Dalam jangka panjang bahkan dapat membahayakan, seperti kecelakaan akibat kursi yang patah. 


\section{Keahlian Dosen}

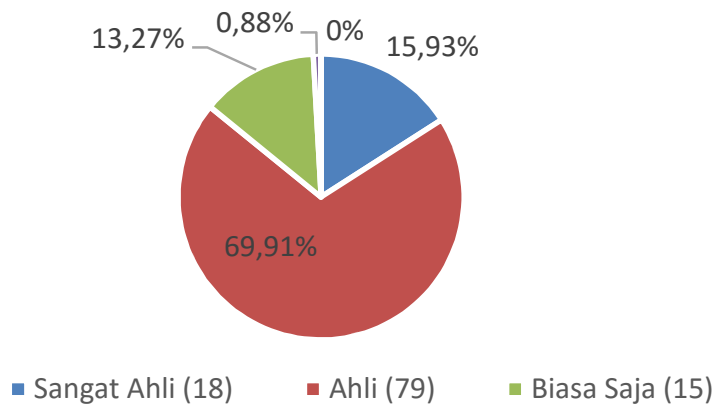

Gambar 5. Keahlian Dosen

Sumber : Hasil Riset 2015

9,91\% responden menyatakan bahwa dosen pengampu praktikum di lab tergolong ahli. Indikasinya menyatakan bahwa kegiatan praktikum sudah berjalan sesuai dengan harapan responden, mendapatkan pengalaman simulasi bekerja yang mendekati keadaaan sebenarnya dan didukung dengan pembekalan yang baik. Dalam jangka panjang, para dosen diharapkan terus meningkatkan keahliaannya agar dapat mempersiapkan mahasiswa menyongsong MEA.

$15,93 \%$ responden menyatakan bahwa dosen pengampu praktikum di lab sangat ahli mengindikasikan bahwa materi yang dibawakan sudah kekinian dan dapat diserap dengan baik oleh mahasiwa.

\section{Jumlah Tugas}
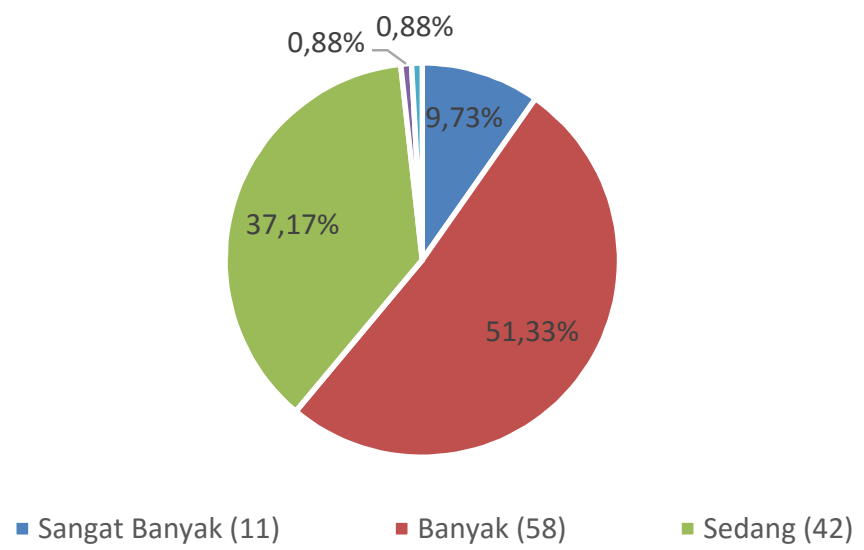

Gambar 6. Jumlah Tugas

Sumber : Hasil Riset 2015 
$51,33 \%$ responden menyatakan bahwa tugas-tugas yang diberikan dosen jumlahnya banyak, mengindikasikan bahwa materi pengajaran cukup banyak. Perlu adanya evaluasi, agar kualitas pengajaran dapat berlangsung konsisten, tugas diberikan sesuai dengan kemampuan mahasiswa. Ketepatan komposisi tugas dengan pemberian materi merupakan kunci sukses berlangsungnya kegiatan di laboratorium.
$37,17 \%$ responden menyatakan bahwa tugas-tugas yang diberikan dosen jumlahnya sedang merupakan indikator bahwa dalam beberapa materi sudah terjadi keseimbangan yang baik antara pemberian materi dengan tugas. Keseimbangan dapat merangsang mahasiswa semakin kreatif dan memanfaatkan waktu secara optima .

\section{Bantuan Dosen}

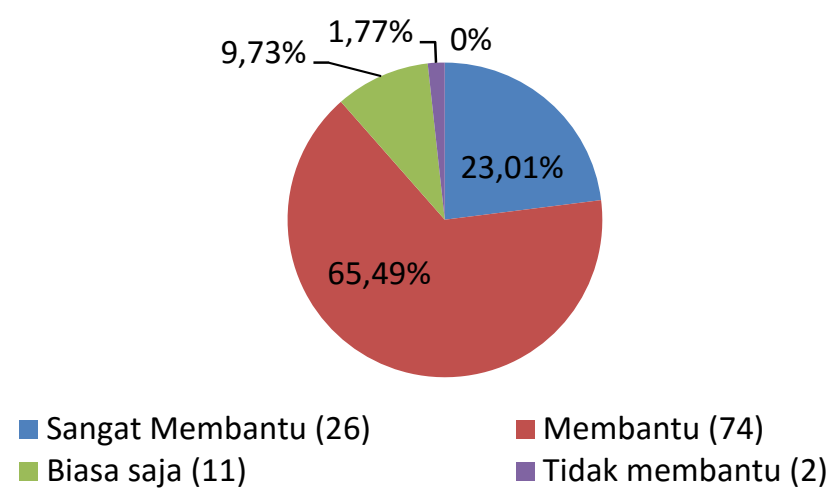

\section{Gambar 7. Bantuan Dosen}

Sumber : Hasil Riset 2015

65, $49 \%$ responden menyatakan bahwa dosen membantu jika ada permasalahan merupakan indikator yang baik dan perlu ditingkatkan. Asistensi dalam praktikum merupakan hal mutlak, dikarenakan praktikum bagi sebagian besar mahasiswa dapat saja merupakan hal yang baru dan perlu didampingi secara intensif. 23,01 \% responden menyatakan bahwa dosen sangat tidak membantu jika ada permasalahan merupakan indikator yang mengkhawatirkan. Evaluasi dan observasi perlu dilakukan pada beberapa sesi. Ada beberapa pemikiran yang timbul, kemungkinannya karena kualitas pengajaran yang tidak baik atau komposisi antara dosen dan mahasiswa di lab kurang memadai, sehingga rentang kendalinya tidak dapat berlangsung lancar. 


\section{Kebersihan Lab}

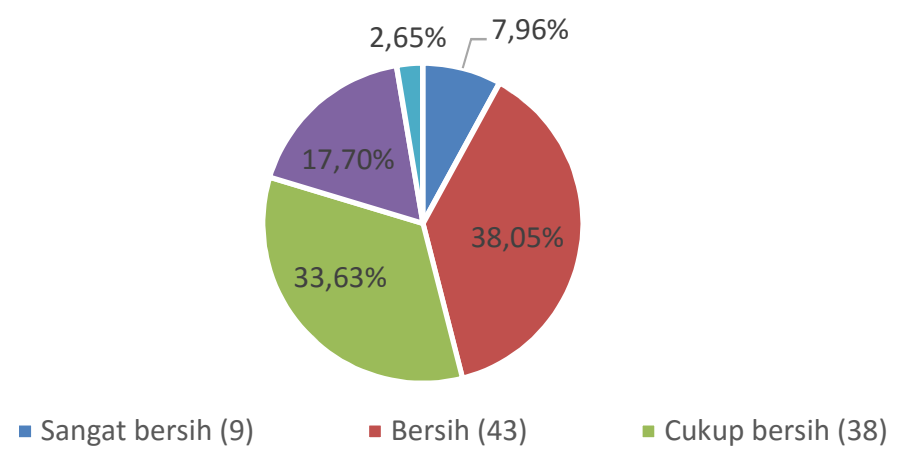

\section{Gambar 8. Kebersihan Lab}

Sumber : Hasil Riset 2015

38, $05 \%$ responden menyatakan bahwa lab bersih, mencerminkan pemeliharaan yang sudah sesuai standar. Namun peningkatan pemeliharaan kebersihan lab merupakan keharusan. Lab yang bersih merupakan cerminan kesungguhan pengelolanya dalam menciptakan atmosfir belajar mengajar yang nyaman dan professional.

\section{Kerapihan Lab}

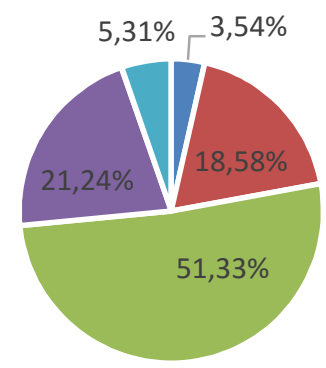

$$
\text { - Sangat rapih (4) - Rapih (21) = Cukup rapih (58) }
$$

\section{Gambar 9. Kerapihan Lab}

Sumber : Hasil Riset 2015

$51,33 \%$ responden menyatakan bahwa lab cukup rapih, indikasinya mengkhawatirkan. Kondisi di dunia industri memperlihatkan bahwa kerapihan tempat bekerja merupakan hal mutlak. Jika mahasiswa terbiasa berpraktek dalam suasana yang kurang rapih, dapat saja berlanjut menjadi kebiasaan tidak menjaga kerapihan 
tempat magang ataupun tempat bekerjanya

merugikan bagi para alumni lainnya di masa kelak. Institusi pendidikan akan mendapatkan mendatang.

cap yang tidak baik dari industi, dan sangat

\section{Antusiasme Mahasiswa}
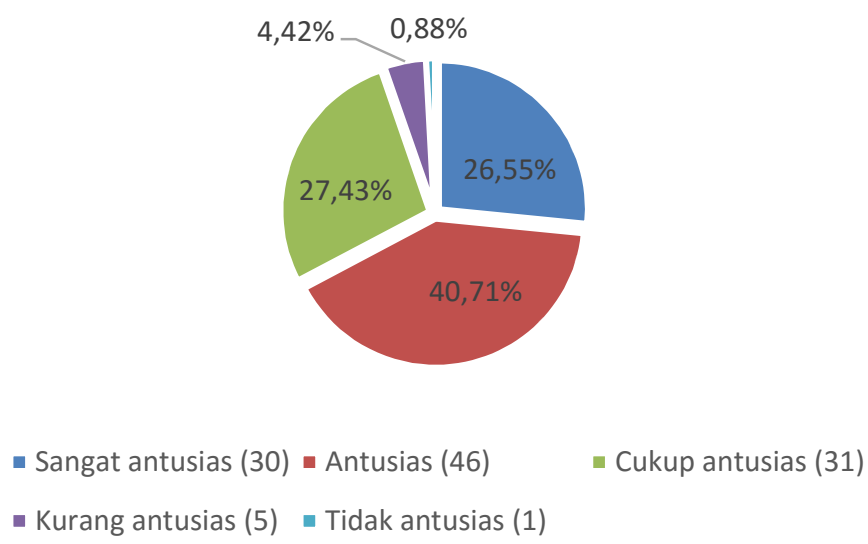

\section{Gambar 10. Antusiasme Mahasiswa}

Sumber : Hasil Riset 2015

$40,71 \%$ responden menyatakan antusias merupakan indikasi yang mengkhawatirkan. mengindikasikan bahwa lab merupakan Perlu adanya evaluasi dan observasi lanjutan, tempat menarik sebagai ajang meningkatkan mencari faktor-faktor yang mengakibatkan kompetensi dan berkreasi. lab menjadi tempat yang membosankan.

$26,55 \%$ responden menyatakan tidak antusias

\section{Manfaat Materi}

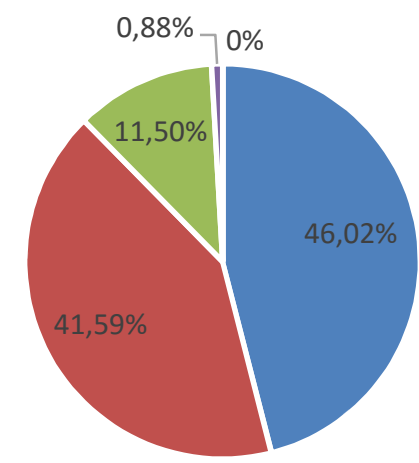

- Sangat bermanfaat (52) - Bermanfaat (47)

- Cukup bermanfaat (13) - Kurang bermanfaat (1)

\section{Gambar 11. Manfaat Materi}

Sumber : Hasil Riset 2015 
$46,02 \%$ responden menyatakan bahwa materi yang diberikan dosen tidak bermanfaat mengindikasikan bahwa perlunya tinjauan ulang terhadap seluruh modul praktikum dan cara menyampaikannya. Perlunya membandingkannya lagi dengan kondisi dunia kerja yang nyata, dengan mendatangi industri secara langsung ataupun dengan melihat simulasi praktikum melalui youtube dan media lainnya.

\section{KESIMPULAN DAN SARAN}

\section{Kesimpulan}

Dari hasil penelitian yang telah dilakukan dan disusun diatas, maka dapat diambil beberapa kesimpulan sebagai berikut :

a. Dari aspek kualitas pengajaran di laboratorium secara umum atau ngada di laboratorium peralatan mayoritas responden menyatakan bahwa kualitas pengajaran praktikum oleh para dosen lab cukup baik karena diampu oleh para dosen yang ahli dan meiliki pengalamanbaik di lingkungan kerja maupun dilingkungan akademik/pendidikan. Hal ini juga ditopang oleh respon dari mayoritas mahasiswa yang menjadi sampel penelitian ini bahwa dosen-dosen yang mengajar praktikum siap selalu dalam membantu permasalah mashasiswa di laboratorium.

Dari aspek kelengkapan peralatan sebagian besar atatu mayoritas responden menyatakan bahwa kelengkapan peralatan yang ada dilaboratoriu ada pada tingkat sedang. Hal ini berarti masih perlunya penmbahan peralatan yang diperlukan untuk menyempurnakan peralatan yang memang masih agak kurang seperti komputer yang masih sedikit, pesasat telepon serta alat-alat lainnya. Termasuk dari aspek jumlah meja dan kursi yang ada di dalam laboaratorium menurut mayoritas penilaian responden dianggap sudah kurang ideal.

b. Sementara aspek lainnya seperti kebersihan laboratorium menurut mayoritas resonden dapa dikatakan bersih, walupun kadang-kadang ada sampahsampah kecil yang disebabkan oleh pergantian kelas sebelumnya dimana petugas kebersihan belum sempat membersihkannya.

Sementara materi lab dianggap mayoritas respon cukup baik dan memiliki banyak manfaat, khususnya ketika masuk ke dunia kerja kelak.

\section{DAFTAR PUSTAKA}

Neuman, W. Lawrence, Metode Penelitian Sosial : Pendekatan Kualitatif dan Kuantitatif, diterj. Edina T. Sofia, PT. Index Permata Puri Media, Jakarta, 2011.

Suyanto, Bagong dan Sutinah, edit, Metode Penelitian Sosial, Berbagai Alternatif Pendekatan, Prenada Media, Jakarta, 2009 
ANALISIS PERSEPSI KUALITAS PERKULIAHAN DI LABORATORIUM PERKANTORAN

DAN SEKRETARI PROGRAM PENDIDIKAN VDKASI UNIVERSITAS INDQNESIA

Istiadi, Mahammad Ridha

Volume 4 Nomor I, pp 63-75

Wibowo, Prilaku dalam Organisasi, Raja Grafindo Persada, Jakarta 2014

Sunyoto, Danang, Teori, Kuessioner dan Analisis Data (Praktek Penelitian), CAPS,

Jakarta, 2012

Fuad, Anis dan Kandung Smito Nugroho, Pandauan Praktis Penelitian Kualitatif , Graha Ilmu, Jakarta 2014 